\title{
ANALYSIS OF THE COST OF FOREST HARVESTING FOR THE PRODUCTION OF CHARCOAL FOR IRON AND STEEL INDUSTRY
}

\author{
Guilherme Carvalho Lana ${ }^{1 *}$, Romano Timofeiczyk Junior ${ }^{2}$, Dimas Agostinho da Silva ${ }^{3}$, Ricardo Anselmo \\ Malinovski $^{4}$, David Alexandre Buratto ${ }^{5}$
}

\begin{abstract}
1* Operations Manager, Wood Bio Energia, Sete Lagoas, Minas Gerais, Brazil - guilherme.carvalho@ woodbioenergia.com.br ${ }^{2}$ Federal University of Paraná, Department of Economics and Rural Extension, Curitiba, Paraná, Brazil - romano.timo@gmail.com ${ }^{3}$ Federal University of Paraná, Department of Economics and Rural Extension, Curitiba, Paraná, Brazil - dimas.agostinho.silva@ gmail.com ${ }^{4}$ Federal University of Paraná, Department of Economics and Rural Extension, Curitiba, Paraná, Brazil - ricardomalinovski@ gmail.com ${ }^{5}$ Federal University of Paraná, Program in Forest Engineering, Curitiba, Paraná, Brazil - davidburatto@ gmail.com*
\end{abstract}

Received for publication: 06/12/2016 - Accepted for publication: 08/06/2018

\begin{abstract}
This study aimed to analyze the production cost structure of the system of short logs, operating with the log lengths of $2.1 \mathrm{~m}, 3.7 \mathrm{~m}$ and $5.0 \mathrm{~m}$ and to determine which of the three log lengths enables a lower final cost in the production of charcoal. Data collected from a forestry company in the municipality of Paraopeba (state of Minas Gerais, Brazil) were used. An analysis of the cutting process, the transportation and the charcoal production was performed. The results showed that the hourly cost of the short log system is higher when using larger log lengths. The cost per unit quantities (cubic meters and tons) of treatments with longer logs is smaller due to its higher yield time. The system with logs of $5.0 \mathrm{~m}$ presents an inferior cost for the production of charcoal when compared to the same system with logs between $3.7 \mathrm{~m}$ and $2.1 \mathrm{~m}$ of length.

Keywords: Eucalyptus, production costs, charcoal production.
\end{abstract}

\section{Resumo}

Análise dos custos de colheita florestal para produção de carvão vegetal siderúrgico. Este trabalho teve como objetivo analisar a estrutura dos custos de produção do sistema de toras curtas, operando com os comprimentos de toras de 2,1 m, 3,7 m e 5,0 m e determinar qual dos três comprimentos de tora possibilita um menor custo final na produção de carvão vegetal. Foram utilizados dados coletados de uma empresa florestal, no município de Paraopeba (MG). Foi realizada uma análise do processo de corte, do processo de baldeio e do carvoejamento. Os resultados demonstraram que o custo horário do sistema de toras curtas é superior ao se utilizarem maiores comprimentos de toras. O custo por unidade de grandezas (metros cúbicos e toneladas) dos tratamentos com toras mais longas é menor devido ao seu maior rendimento horário. O sistema com toras de 5,0 $\mathrm{m}$ apresenta custo de produção de carvão vegetal inferior quando comparado ao mesmo sistema com toras de comprimento entre $3,7 \mathrm{~m} \mathrm{e} 2,1 \mathrm{~m}$.

Palavras-Chave: Eucalipto, custos de produção, carvoejamento.

\section{INTRODUCTION}

In any industrial or commercial activity, cost is an important variable for success. The lower the costs, the greater the probability of making a profit in the developed business, as long as the quality of the final product is maintained, or even improved. According to Tanaka (1986), forest harvesting is the item with the highest cost of operations, which may represent approximately $80 \%$ of the cost of forest formation in conditions of cutting per cubic meter.

According Burla et al. (2012), the main causes of increasing mechanization of forest harvesting operations are the search for increased productivity and the need to keep operating expenses low and constant, thus reducing the production costs of a particular activity. For Malinovski and Malinovski (1998), the forest harvesting process involves all the partial activities from cutting to installation in the courtyard of the consumer industry.

The reduction of harvesting costs is directly related to the definition of the system to be used, the choice of equipment and the way of working. The knowledge about the operational cost of machines is of paramount importance in the decision-making process, helping essentially the way the control and planning of the use of this equipment (MACHADO; MALINOVSKI, 1988).

Deciding which harvesting system to use and in what form this system will be used is based on economy. Consequently, it is necessary to carry out studies that take into account different ways of operating the system and its effects on production and especially on the quality of charcoal and not just the cost of each system.

FLORESTA, Curitiba, PR, v. 48, n. 4, p. 453-462, out/dez. 2018

Lana. G. C et.al.

ISSN eletrônico 1982-4688

DOI: $10.5380 /$ rf.v48i4.49607 
Forest harvesting activities directly influence the Brazilian steel industry, which uses wood extracted from forest plantations in its kilns. The quality of the charcoal produced is influenced by the system used for the extraction and processing of wood. According to the Brazilian Tree Industry (IBÁ, 2016), 21.25 million $\mathrm{m}^{3}$ of wood for charcoal production were consumed in Brazil in 2015.

According to Vital and Pinto (2011), Minas Gerais, Pará, Maranhão, Mato Grosso do Sul and Espírito Santo are the main charcoal producing poles in the country. According to Mota (2013), the state of Minas Gerais has the largest forest area for charcoal production, and in 2015, 678,401 ha of forests belonged to the charcoal-based steel and iron industry. In addition, the state consumes approximately $60 \%$ of the charcoal produced in the country. According to the Union of the Metallurgical Industry and Electric Material (SINDIFER, 2016), in 2015, Brazil produced approximately 32.1 million tons of pig iron, out of which approximately $20.2 \%$ were produced using charcoal.

Studies were conducted in relation to the analysis of the costs involved in the production of charcoal: Castro et al. (2007) analyzed the economic profitability of charcoal production; Santos and Hatakeyama (2012) compared productive systems, emphasizing the economic, social and environmental aspects; Oliveira (2012) studied the kiln-furnace system for the production of charcoal; Mota (2013) studied the productive chain of vegetable charcoal in Brazil, derived from planted forest; Silva et al. (2014) evaluated the economic viability of production systems of this product; and Silva and Farias (2015) economically researched the production of forest plantations as raw material.

Therefore, the scarcity of studies on costs related to forest harvesting for charcoal production motivated this research. In light of this context, this study aimed to analyze the costs of forest harvesting for the production of charcoal for iron and steel industry. To this end, the structure of production costs of the short logs system was examined, operating with log lengths of $2.1 \mathrm{~m}, 3.7 \mathrm{~m}$, and $5.0 \mathrm{~m}$. In addition, it was identified which of the three log lengths permits the lowest final cost in the production of charcoal for iron and steel industry.

\section{MATERIAL AND METHODS}

\section{Area of study}

The present study was carried out according to the areas developed by a company located in the state of Minas Gerais, Brazil. The forest stands were clones of the genus Eucalyptus for the production of seven years-old charcoal, with a spacing of $2 \times 3$ meters and a volumetric productivity of approximately 224 cubic meters per hectare in the harvest period.

\section{Harvesting and transportation of wood}

Harvesters were used to cut and process wood in the field. The equipment used was a Caterpillar base machine model 320D L, with net power of $138 \mathrm{HP}$, and a Komatsu Forest 370e head. The machines performed the cutting, delimbing and sectioning activities in three lengths: $2.1 \mathrm{~m}, 3.7 \mathrm{~m}$ and $5.0 \mathrm{~m}$ (Treatments), by separating the logs into fine ones (the upper two thirds of each tree) and coarse ones (the lower third of each tree). In this stage, the volume of cut wood, the hours worked, the consumption of diesel oil, the consumption of lubricating oil and the consumption of current oil (values used in the composition of the costs of production) were measured using the on-board computer of the equipment.

In order to carry out the transportation of the material, Valtra forwarders model BH 180 were used. At this stage, the volume of transported wood was measured using a cubing factor for each log length. This factor was determined by samples of the transported loads, hours worked and consumption of diesel oil (values used in the composition of production costs). From this step, the number of treatments analyzed was doubled due to the separation between logs classified as coarse and fine, performed in the previous stage.

The transportation of the wood to the charcoal making boxes was carried out with Volkswagen forwarders, model VW $242506 \mathrm{X} 2$. In this stage, only the mass transported was measured, using a truck scale (because it was an outsourced operation), and the cost was generated through the amount paid per ton transported.

\section{Data collection}

During the study, data originated from 18 work shifts of 9 hours each for the Harvester, 54 work shifts of 9 hours each for the Forwarder, and 36 cycles for the charcoal making were collected. For this phase, no statistical tests were performed about the volume of data that should be collected, since the maximum possible data were collected, taking into account the operational activity of each equipment or step and the time of field research.

The equipment was analyzed using the three log lengths defined as treatments $(2.1 \mathrm{~m}, 3.7 \mathrm{~m}$ and $5.0 \mathrm{~m})$ because they are, according to Mota (2013), the dimensions used in the cutting of eucalyptus wood for the charcoal production. A survey about the technical characteristics and conditions of use of the mechanized assemblies was conducted. Then, the productivity of the equipment in the different situations and with the use of the process of 
separation of fine and coarse logs was identified. To this end, the lower third of the tree was separated as coarse firewood and the upper two thirds as fine firewood.

The Harvester and the Forwarder always worked in similar situations, such as relief, forest productivity and soil type, to allow a perfect comparison between the processes being studied. The data used in calculating the operational cost of the equipment was provided by the company.

\section{Charcoal making}

Six rectangular kilns, model FR 230, were used, with a maximum capacity of 190 st and a minimum capacity of $160 \mathrm{st}$. The dimensions of the kilns used are: $14.31 \mathrm{~m}$ long, $4.5 \mathrm{~m}$ wide and $2.85 \mathrm{~m}$ standing right (Figure 1). To load the kiln, a Volvo loader model L60f, was used, adapted with a special TMO crane. In the stage of loading the kiln, the hours worked and the mass of wood moved to the composition of the costs were measured, since it is an outsourced operation and the cost was generated through the amount paid per hour worked.

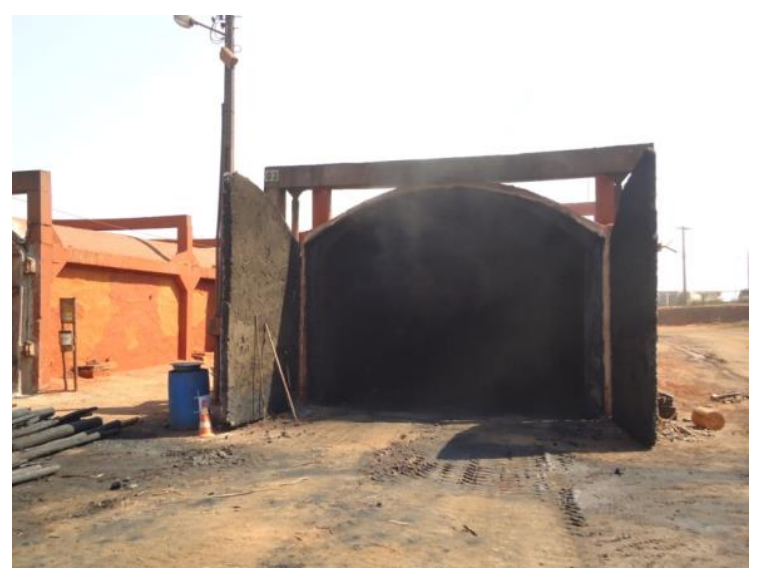

Figure 1. Front view of the FR 230 kiln used in the charcoal making stage.

Figura 1. Vista frontal do forno FR 230 utilizado na etapa de carbonização. Source: Own elaboration (2012).

For the unloading of the furnace, a Volvo loader, model L60f, was used, adapted with a scale for the determination of the mass of the charcoal unloaded. The kilns were opened when its average temperature reached $60{ }^{\circ} \mathrm{C}$, a process currently used by the company in its commercial production. The non-pyrolyzed material, known as incompletely carbonized residue, according to Sharma et al. (2015), is the result of the incomplete decomposition caused by the use of lower temperatures. The material generated was measured using a truck scale.

The charcoal storage was carried out in a previously demarcated area for each batch, being covered with tarpaulin to avoid the humidity. The total time of unloading was determined by the opening of the kiln door until the complete removal of the charcoal. At the phase of unloading the kiln, the hours worked, the mass of charcoal unloaded, and the mass of the log generated in the process were measured, since this operation was an outsourced operation and the cost was generated through the amount paid per hour worked.

\section{Fixed costs of harvesting}

For the determination of fixed costs for the Harvester and the Forwarder, the annual cost of depreciation and interest, which consists of the annual interest expenses, and the annual cost of linear depreciation of the equipment, plus the cost of labor operators were used. This method was used by the analyzed company. The annual interest rate used was $12 \%$ per year, the same used by the company. This rate was also chosen because, according to Rezende and Oliveira (2013), forest projects are characterized by their long terms, making them riskier, besides being based on the work of Castro et al. (2007). The service life of the equipment was 20,000 hours or 4.64 years, values used by the company and Freitas et al. (2004). The methodology of calculation for obtaining the fixed costs of harvesting is described below, the same procedure used by Burla et al. (2012) and Silva et al. (2014).

a) Calculation of depreciation and interest

In order to obtain the depreciation values for the machinery, Equation 1 was used, as suggested by Burla et al. (2012).

$$
D=\frac{(V a-V r)}{H}
$$

FLORESTA, Curitiba, PR, v. 48, n. 4, p. 453-462, out/dez. 2018

Lana. G. C et.al.

ISSN eletrônico 1982-4688

DOI: $10.5380 /$ rf.v48i4.49607 
In which: D: depreciation (R \$/year); Va: acquisition value of equipment (R\$); Vr: residual value of the equipment; and $\mathrm{H}$ : equipment service life (20,000 hours).

Furthermore, following the methodology proposed by Burla et al. (2012), the interest on the machinery was calculated, according to Equation 2.

$$
J=\frac{V a \times i \times f}{H}
$$

In which: J: interest; Va: acquisition value of equipment (R\$); i: annual interest rate (12\% per year); f: factor that corrects the value of the equipment due to depreciation (0.5); and H: equipment service life (20,000 hours).

The operating and production costs of the mechanized assemblies were quantified, including the incomes and costs of the labor involved. To calculate the cost of production, Equation 3 was used, as proposed by Milan and Rosa (2015).

$$
C H C=\frac{C A D J}{H E A}
$$

In which: CHC: hourly cost of capital (R\$/h); CADJ: annual cost of depreciation and interest (R $\$ / y e a r)$; and HEA: hours actually worked per year (h/year).

b) Cost of labor

The average labor cost, as suggested by Silva et al. (2014) and Jasper and Silva (2013), was determined as shown below (Equation 4). Data for this calculation were provided by the company.

$$
M D O=\frac{\operatorname{Sop}(1+E s)}{H T M}
$$

In which: MDO: labor cost per effective hour (R $\$ / \mathrm{h})$; Sop: sum of the monthly salaries of the operators $(\mathrm{R} \$)$; Es: social charges (\%); and HTM: hours actually worked in the month (h).

c) Total average fixed cost

According to Mota (2013), the total average fixed cost is described according to Equation 5.

$$
C F M T=\frac{C T}{P r}
$$

In which: CFMT: total average fixed cost $\left(\mathrm{R} \$ / \mathrm{m}^{3}\right)$; CT: hourly cost of capital $(\mathrm{R} \$ / \mathrm{h})$ plus labor cost per hour $(\mathrm{R} \$ / \mathrm{h})$; and Pr: Productivity $\left(\mathrm{m}^{3} / \mathrm{h}\right)$.

\section{Variable costs of harvesting}

The quantification of the average variable costs of harvesting consisted of the sum of the hourly costs with maintenance and hourly costs with fuels and lubricating oils. The cost of maintenance consisted of the sum of the annual expenses with maintenance train, chain and saber, conveyors or tires, parts and/or components and maintenance services, divided by the hours actually worked during the year, according to the methodology also used by Simões et al. (2014). Values were calculated using the company's historical data series. For the calculation, the values currently used by the company for the composition of its costs were considered.

The fuel cost was obtained by adding up the costs of diesel oil, lubricating oil and current oil to the Harvester. The market prices paid by the company for the purchase of diesel, lubricating and common oil in the period x of variable costs of Machado and Malinovski (1988) were used.

\section{Cost of harvesting in the production of charcoal}

In order to identify the cost of harvesting in the production of charcoal, the costs of harvesting were converted from $\mathrm{R} \$ / \mathrm{m}^{3}$ to $\mathrm{R} \$ / \mathrm{t}$ (Equation 7) to enable comparison with the mass of charcoal produced, using the density of wood previously measured by the company through the precutting inventory, performed in the field used for the experiment, according to Coelho et al. (2016).

$$
C C t=\frac{C C}{d}
$$

In which: $\mathrm{CCt}$ : total cost of harvesting per ton $(\mathrm{R} \$ / \mathrm{t}) ; \mathrm{CC}$ : total cost of harvesting per cubic meter $\left(\mathrm{R} \$ / \mathrm{m}^{3}\right)$; and $\mathrm{d}$ : density $\left(0.495 \mathrm{~g} / \mathrm{cm}^{3}\right)$. 
After cost conversion, the cost of harvesting in the production of charcoal using the gravimetric yield was established. This yield was generated from the average of the gravimetric yields of the treatments using fine and coarse logs of the same length (Equation 8).

$$
C C V=\frac{C C t}{R G} \times 100
$$

In which: CCV: cost of harvesting in the production of charcoal $(\mathrm{R} \$ / \mathrm{t}) ; \mathrm{CTt}$ : total cost of harvesting per ton $(\mathrm{R} \$ / \mathrm{t})$; and RG: gravimetric yield (\%).

To perform the descriptive statistical analyzes, the Bartlett Test, available in the SAS Learning Edition, was used. This statistical tool tested the hypothesis that the variables analyzed had correlation.

\section{RESULTS}

\section{Fixed costs of harvesting}

The total fixed hourly costs generated by the harvesting activity are shown in Figure 2.

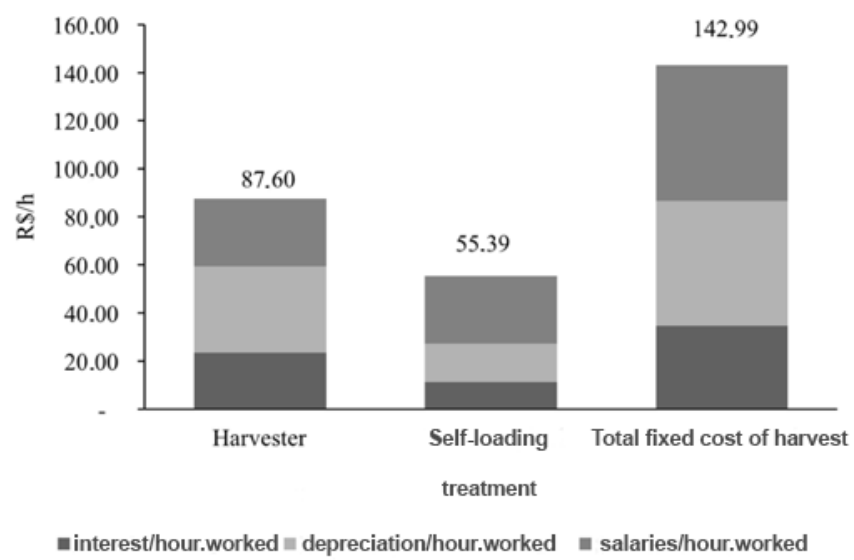

Figure 2. Hourly fixed cost of Harvester and Forwarder $(\mathrm{R} \$ / \mathrm{h})$.

Figura 2. Custo fixo horário do Harvester e do Auto carregável (R \$/h).

\section{Variable costs of harvesting}

In Figure 3, it can be seen that the hourly cost of Harvester increased with the increase of the length of the logs used.

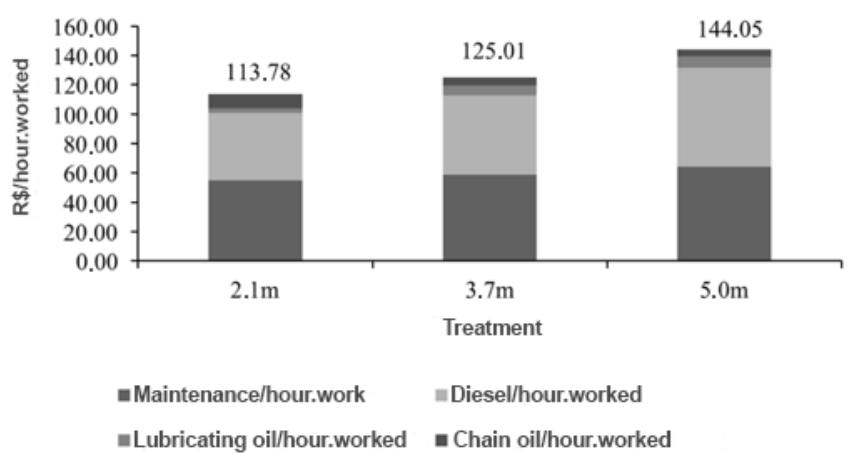

Figure 3. Harvester total variable costs in different treatments (R \$/ worked hours).

Figura 3. Custos variáveis totais do Harvester nos diferentes tratamentos (R $\$ / \mathrm{h}$.trabalhada).

Considering that the equipment had different yields in each treatment, the average variable cost per unit produced, consequently, also presented difference, since the total variable costs were diluted in the costs per unit of the treatments, which present higher yields (Figure 4). Therefore, the average variable costs were lower in treatments with higher log lengths.

FLORESTA, Curitiba, PR, v. 48, n. 4, p. 453-462, out/dez. 2018

Lana. G. C et.al.

ISSN eletrônico 1982-4688

DOI: $10.5380 /$ rf.v48i4.49607 


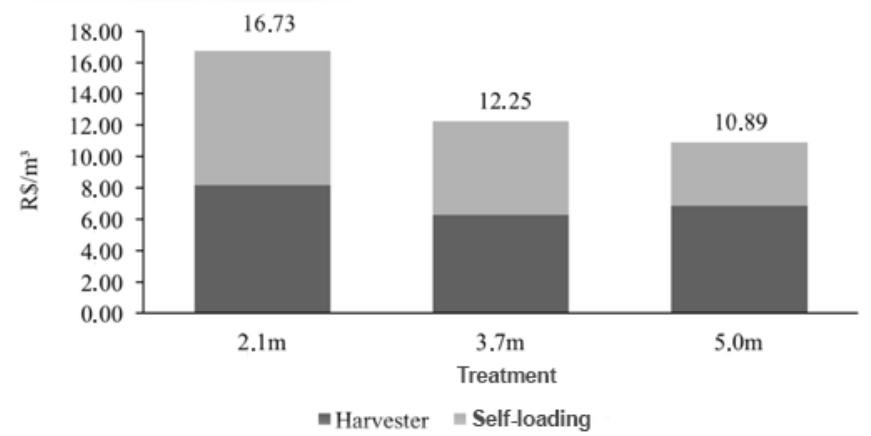

Figure 4. Average variable cost of Harvester and Forwarder in the different treatments $\left(\mathrm{R} \$ / \mathrm{m}^{3}\right)$.

Figura 4. Custo variável médio do Harvester e Auto carregável nos diferentes tratamentos $\left(\mathrm{R} \$ / \mathrm{m}^{3}\right)$.

\section{Average harvesting cost}

In Figure 5, the average costs of harvesting in the production of charcoal by equipment in different log lengths analyzed are shown.

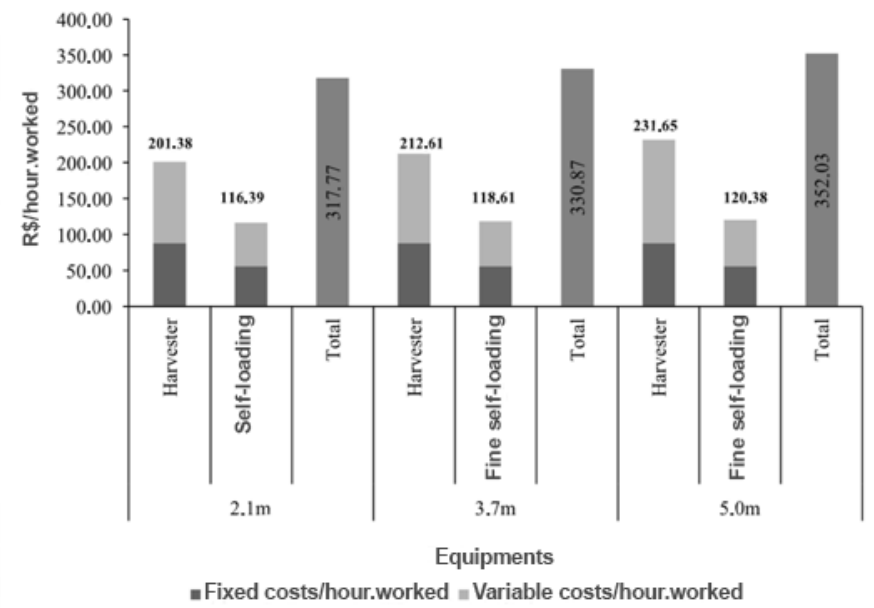

Figure 5. Total costs of harvesting activity in the different treatments (R \$ / hour worked).

Figura 5. Custos totais da atividade de colheita nos diferentes tratamentos (R $\$ /$ h.trabalhada).

The total costs per cubic meter and per ton in the harvesting activity are shown graphically in Figure 6. It can be seen that the total hourly costs were higher in the activities in which logs of longer lengths were used.

A)

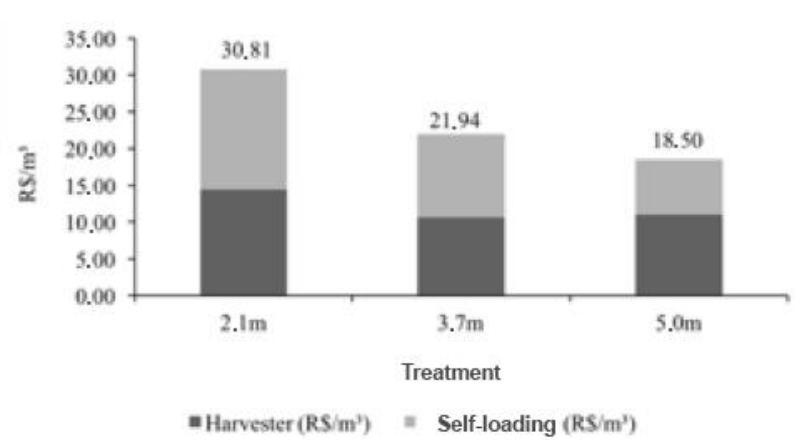

B)

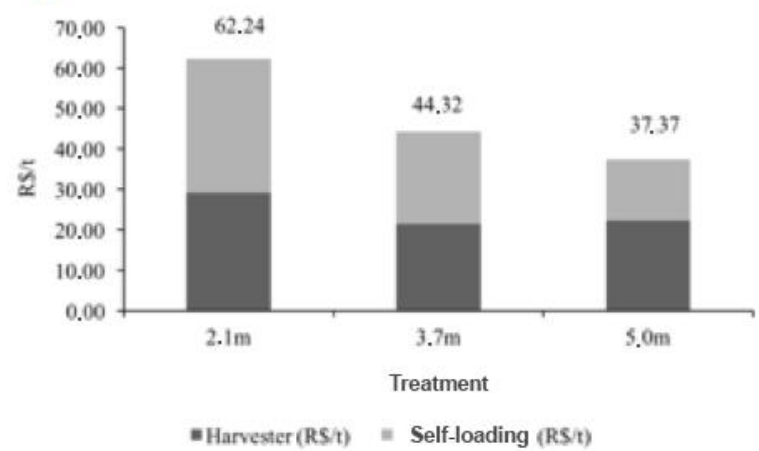

Figure 6. Total costs per cubic meter of harvesting activity $\left(\mathrm{R} \$ / \mathrm{m}^{3}\right)(\mathrm{A})$ and total costs per ton of harvesting activity $(\mathrm{R} \$ / \mathrm{t})(\mathrm{B})$. Cost of loading and unloading the kiln.

Figure 6. Total cost of harvesting per cubic meter $\left(\mathrm{R} \$ / \mathrm{m}^{3}\right)(\mathrm{A})$ and total cost per ton of harvesting $(\mathrm{R} \$ /$ ton $)(\mathrm{B})$. 
Costs of loading and unloading the kiln

In Table 1, the costs of loading and unloading the kiln at different log lengths (treatments) are described.

Table 1. Cost of loading and unloading of the kiln in the different treatments $(\mathrm{R} \$ / \mathrm{t})$.

Tabela 1. Custo do carregamento e descarregamento do forno nos diferentes tratamentos (R $\$ / \mathrm{t})$.

\begin{tabular}{lllll}
\hline \multirow{2}{*}{ Treatment } & \multicolumn{2}{c}{ Loading } & \multicolumn{2}{c}{ Donwloading } \\
\cline { 2 - 5 } & Fine firewood $(\mathbf{R} \$ \mathbf{t})$ & Coarse firewood $(\mathbf{R} \$ \mathbf{t})$ & Fine firewood $(\mathbf{R} \$ \mathbf{t})$ & Coarse firewood $(\mathbf{R} \$ / \mathbf{t})$ \\
\hline 2.10 & 5.24 & 4.91 & 9.68 & 10.39 \\
3.70 & 3.68 & 3.64 & 9.25 & 9.96 \\
5.00 & 2.67 & 2.74 & 9.06 & 8.95 \\
\hline
\end{tabular}

\section{Cost of harvesting in the production of charcoal}

Taking into account the gravimetric yield, the cost per ton for charcoal production was observed for each of the treatments and the percentage participation of each operation in the reduction of the average cost, as shown in Table 2.

Table 2. Cost per ton for the production of charcoal in each treatment.

Tabela 2. Custo por tonelada para a produção de carvão vegetal em cada tratamento.

\begin{tabular}{|c|c|c|c|c|c|c|c|c|c|}
\hline \multirow{2}{*}{ Activity } & \multicolumn{3}{|c|}{ Cost $(R \$ / t)$} & \multicolumn{3}{|c|}{ Differences (\%) } & \multicolumn{3}{|c|}{$\begin{array}{c}\text { Participation in } \\
\text { total cost }(\%)\end{array}$} \\
\hline & $2.1 \mathrm{~m}(\mathrm{I})$ & $3.7 \mathrm{~m}(\mathrm{II})$ & $5.0 \mathrm{~m}($ III) & II - I & III - I & III - II & II - I & III - I & III - II \\
\hline Unloading in the kilns & $\mathrm{R} \$ 10.04$ & $\mathrm{R} \$ 9.51$ & $\mathrm{R} \$ 9.00$ & -5.3 & -11.6 & -5.7 & 1.0 & 1.3 & 2.2 \\
\hline Loading in the kilns & $\mathrm{R} \$ 14.24$ & $\mathrm{R} \$ 10.29$ & $\mathrm{R} \$ 7.59$ & -27.7 & -87.6 & $-35,6$ & 7.2 & 8.6 & 11.9 \\
\hline Transport & $\mathrm{R} \$ 33.70$ & $\mathrm{R} \$ 33.70$ & $\mathrm{R} \$ 33.70$ & 0.0 & 0.0 & 0.0 & 0.0 & 0.0 & 0.0 \\
\hline Self-loading & $\mathrm{R} \$ 93.01$ & $\mathrm{R} \$ 64.08$ & $\mathrm{R} \$ 42.43$ & -31.1 & -119.2 & -51.0 & 52.8 & 65.2 & 95.3 \\
\hline Harvester & $\mathrm{R} \$ 81.77$ & $\mathrm{R} \$ 60.38$ & $\mathrm{R} \$ 62.51$ & -26.2 & -30.8 & 3.4 & 39.0 & 24.8 & -9.4 \\
\hline Total & $\mathrm{R} \$ 232.76$ & $\mathrm{R} \$ 177.96$ & $\mathrm{R} \$ 155.23$ & -23.5 & -49.9 & -14.6 & -- & -- & -- \\
\hline
\end{tabular}

\section{DISCUSSION}

\section{Fixed costs of harvesting}

Considering that the equipment presented different yields in each treatment, the average fixed cost per unit produced also presented changes, since the total fixed costs were diluted in the costs per unit of the treatments that presented the highest yields (Figure 2). Therefore, average fixed costs per unit were lower at the higher log lengths.

\section{Variable costs of harvesting}

The increase in Harvester's hourly cost occurred with the increase of the length of the logs used. This occurs due to increased maintenance and fuel costs as the equipment has been subjected to a greater effort by cutting and processing larger logs.

In relation to the variable cost of the Forwarder, there was an increase in the hourly cost when using logs of greater length, as observed in the Harvester. This increase in costs was generated by higher maintenance costs, lubricating oil and fuel.

These were the most relevant variable cost components, since more effort was made on the equipment when subjected to the handling of longer logs. According to Figure 4, the average variable costs were lower in treatments with higher log lengths.

\section{Average harvesting cost}

It can be seen in Figure 5 that the average costs increased according to the increase in log length used, presenting the same behavior of variable costs. Fixed hourly costs did not vary. 
It is noted that the cost per cubic meter of Harvester was lower when using logs of $3.7 \mathrm{~m}$, but when analyzing the cost per unit of Harvester and cost per unit of Forwarder, it is noticed that the total costs per unit were lower when using logs with $5.0 \mathrm{~m}$ due to the lower cost of the Forwarder. Costs per ton presented the same cost variation per cubic meter as they were obtained by the correlation between costs per cubic meter and the density of wood obtained through measurements contained in the precutting inventory carried out by the company in the field used for the experiment (Figure 6).

\section{Cost of loading and unloading the kiln}

The cost of loading the kiln was lower in logs with longer lengths, since the cost of this operation is directly related to the yield of the equipment, which was higher when longer logs were used. The cost of unloading was higher when unloading kilns containing charcoal produced by shorter logs, but with a larger volume of charcoal produced, since the cost was generated by the number of hours worked per kiln (Table 1).

\section{Cost of harvesting in the production of charcoal}

It can be observed that the cost of harvesting in the production of charcoal was lower in the longer log lengths used. There was greater representativeness of cutting activities with the Harvester and transportation with the Forwarder in the total cost of the operation, being $76.29 \%$ of the total cost for logs of $2.1 \mathrm{~m}, 72.53 \%$ for $\operatorname{logs}$ of $3.7 \mathrm{~m} 71.69 \%$ for logs of $5.0 \mathrm{~m}$.

When choosing Treatment II instead of Treatment I, costs are reduced by $23.5 \%$ (in this case, Forwarder represents $52.8 \%$ of the total cost and Harvester 39\%). When choosing Treatment III instead of Treatment I, the reduction is $49.9 \%$ in costs (in this case, Forwarder represents $65.2 \%$ of the total cost). Between Treatment III and II, the Forwarded represents $95.3 \%$ of the total cost. In the comparison between the three treatments, it was verified that the use of Treatment III is the one that most causes reduction of the costs generated in harvesting for the production of charcoal of eucalyptus in the state of Minas Gerais, Brazil.

\section{CONCLUSIONS}

- The hourly cost of the short logging system is higher than longer ones.

- The cost per unit of quantities (cubic meters and tons) of the longer log treatments is lower due to their higher hourly yield.

- The system operating with $5.0 \mathrm{~m}$ logs presents lower charcoal production cost when compared to the same system operating with log lengths of $3.7 \mathrm{~m}$ and $2.1 \mathrm{~m}$.

\section{REFERENCES}

ALVES, R. T.; FIEDLER, N. C.; SILVA, E. N.; LOPES, E. S.; CARMO, F. C. A. Análise técnica e de custos do transporte de madeira com diferentes composições veiculares. Revista Árvore, Viçosa, v. 37, n. 5, p.897-904, 2013.

BURLA, E. R.; FERNANDES, H. C.; MACHADO, C. C.; LEITE, D. M.; FERNANDES, P. S. Avaliação técnica e econômica do Harvester em diferentes condições operacionais. Engenharia na Agricultura, Viçosa, v. 20, n. 5, p. 412-422, 2012.

CASTRO, R. R.; SILVA, M. L.; LEITE, H. G.; OLIVEIRA, M. L. R. Rentabilidade econômica e risco na produção de carvão vegetal. Cerne, Lavras, v. 13, n. 4, p. 353-359, 2007.

COELHO, R. M.; LEITE, A. M. P.; LEONEL, M. S.; MATUDA, J. J.; FREITAS, L. C. Avaliação econômica do uso da madeira de eucalipto para diferentes finalidades, na região do Alto Jequitinhonha, MG. Revista Floresta, Curitiba, v. 46, n. 2, p. 155-164, 2016.

IBÁ. Indústria Brasileira de Árvores. Indústria Brasileira de Árvores. Ano base 2015. Brasília, 2016.

FREITAS, L. C.; MARQUES, G. M.; SIlvA, M. L.; MACHADO, R. R..; MACHADO, C. C. Estudo comparativo envolvendo três métodos de cálculo de custo operacional do caminhão bitrem. Revista Árvore, Viçosa, v. 28, n. 6, p. 855-863, 2004.

JASPER, S. P.; SILVA, R. A. P. Estudo comparativo do custo operacional horário da mecanização agrícola utilizando duas metodologias para o Estado de São Paulo. Nucleus, Ituverava, v. 10, n. 2, p. 119-126, 2013.

MACHADO, C. C.; MALINOVSKI, J. R. Ciência do trabalho florestal. Viçosa: Editora UFV, 1988. 
MALinovisi, J. R; MALINOVSKI, R. A. Evolução dos sistemas de colheita de Pinus na Região Sul do Brasil. Curitiba: FUPEF, 1998.

MILAN, M.; ROSA, J. H. M. Corte, Transbordo e Transporte (CTT): Aspectos relevantes e uso da modelagem para o CTT. In: BELARDO, G. C.; CASSIA, M. T.; SILVA, R. P. Processos Agrícolas e Mecanização da canade-Açúcar. Jaboticabal: SBEA, Cap. 18, p. 415-428, 2015.

MOTA, F. C. M. Análise da cadeia produtiva do carvão vegetal oriundo de Eucalyptus sp. no Brasil. 169 f. Dissertação (Mestrado em Ciências Florestais) - Universidade de Brasília, Brasília, 2013.

OLIVEIRA, A. C. Sistema forno-fornalha para produção de carvão vegetal. $64 \mathrm{f}$. Dissertação (Mestrado em Ciência Florestal) - Universidade Federal de Viçosa, Viçosa, 2012.

REZENDE, J. L. P.; OLIVEIRA, A. D. Análise econômica e social de projetos florestais. Viçosa: Editora UFV, 2013.

SANTOS, S. F. O. M.; HATAKEYAMA, K. Processo sustentável de produção de carvão vegetal quanto aos aspectos: ambiental, econômico, social e cultural. Produção, São Paulo, v.22, n.2, p.309-321, 2012.

SHARMA, A.; PAREEK, V.; ZHANG, D. Biomass pyrolysis - A review of modelling, process parameters and catalytic studies. Renewable and Sustainable Energy Reviews, Belfast, v. 50, p. 1081-1096, 2015.

Silva, D. A. L.; CARDOSO, E. A. C.; VARANDA, L. D.; CHRISTOFORO, A. L.; MALINOVSKI, R. A. Análise de viabilidade econômica de três sistemas produtivos de carvão vegetal por diferentes métodos. Revista Árvore, Viçosa, v. 38, n. 1, p. 185-193, 2014.

SILVA, E. N.; MACHADO, C. C.; FIEDLER, N. C. FERNANDES, H. C. PAUlA, M. O.; CARMO, F. C.; MOREIRA, G. R.; COELHO, F. E. Avaliação de custos de dois modelos de Harvester no corte de eucalipto. Ciência Florestal, Santa Maria, v. 24., n. 3, p. 741-748, 2014.

SILVA, F. C. L.; FARIAS, J. A. Análise econômica da produção de Acacia mearnsii de Wild e carvão vegetal no Vale do Caí e Taquari, Rio Grande do Sul. Ciência Rural, Santa Maria, v. 45, n. 5, p. 927-932, 2015.

SIMÕES, D.; FENNER, P. T.; ESPERANCINI, M. S. T. Produtividade e custos do Feller-Buncher e processador florestal em povoamentos de eucalipto de primeiro corte. Ciência Florestal, Santa Maria, v. 24, n. 3, p. 621-630, 2014.

SINDIFER. Sindicato das Indústrias Metalúrgicas e de Material Elétrico do Estado do Espírito Santo. Anuário estatístico Sindifer. Ano base 2015. Belo Horizonte, 2016.

TANAKA, O. P. Exploração e transporte da cultura do eucalipto. Informe agropecuário, n. 141, p. 24-30, 1986.

VITAL, M.H.F.; PINTO, M.A.C. Condições para a sustentabilidade da produção de carvão vegetal para fabricação de ferro-gusa no Brasil. BNDS setorial 30, Brasília, p. 237-297. 2011.

FLORESTA, Curitiba, PR, v. 48, n. 4, p. 453-462, out/dez. 2018

Lana. G. C et.al.

ISSN eletrônico 1982-4688 
FLORESTA, Curitiba, PR, v. 48, n. 4, p. 453-462, out/dez. 2018 Lana. G. C et.al. 